\title{
The prevalence of enteroviruses that cause respiratory infections in patients with influenzavirus $\mathrm{A} / \mathrm{H} 1 \mathrm{~N} 1$ hospitalized in the Lublin province
}

\author{
Adrian Jarzynski*, Agata Dubas, Malgorzata Polz-Dacewicz
}

Department of Virology, Medical University of Lublin, Chodzki 1, 20-093, Lublin, Poland

\begin{tabular}{|c|c|}
\hline ARTICLE INFO & ABSTRACT \\
\hline $\begin{array}{l}\text { Received } 21 \text { October } 2014 \\
\text { Accepted } 20 \text { November } 2014\end{array}$ & $\begin{array}{l}\text { Viruses that cause respiratory tract infections are the most common agents of infectious } \\
\text { diseases in humans throughout the world. A virus that infects the respiratory system, may }\end{array}$ \\
\hline $\begin{array}{l}\text { Keywords: } \\
\text { influenzavirus, } \\
\text { enterovirus, } \\
\text { rhinovirus, } \\
\text { respiratory infections, } \\
\text { coinfection. }\end{array}$ & $\begin{array}{l}\text { induce various clinical symptoms. What is more, the same symptoms may be caused by } \\
\text { different viruses. The aim of the study was to analyze the prevalence of enteroviruses that } \\
\text { cause respiratory infections in patients with influenzavirus A/H1N1 hospitalized in the } \\
\text { Lublin province. The experimental material was throat and nose swabs taken from patients } \\
\text { hospitalized in Lublin and Tomaszow Lubelski. In the group of } 44 \text { patients ( } 20 \text { women } \\
\text { and } 24 \text { men) infected with influenza A/H1N1, the genetic material of enteroviruses was } \\
\text { detected in } 13 \text { patients }(29.5 \%) \text {. Respiratory viruses co-infections are very common in } \\
\text { hospitalized patients. Studies show that co-infection with influenza virus and enterovirus } \\
\text { are more common in children than in adults. Moreover, viral respiratory tract infections } \\
\text { are independent from the patients' gender. }\end{array}$ \\
\hline
\end{tabular}

\section{INTRODUCTION}

Viruses that cause respiratory tract infections are the most common agents of infectious diseases in humans throughout the world. The main factor affecting the rate of infection is the speed of spread of respiratory viruses in the environment. Diseases caused by these viruses usually run smoothly, but can also result in severe complications, and in the worst cases, death [3].

A virus that infects the respiratory system may induce various clinical symptoms. What is more, the same symptoms may be caused by different viruses. Therefore, the material obtained from the upper respiratory tract must be examined in various ways [2].

Viruses of the human respiratory system. Most of the respiratory pathogens are RNA viruses. These are: the influenza virus; paramyxoviruses - the parainfluenza virus and RSV; picornaviruses - rhinoviruses and enteroviruses; coronaviruses. Respiratory viruses of genetic material that is DNA, are deemed 'adenoviruses'.

The influenza virus. Influenza is a highly contagious respiratory disease, known since ancient times.

Corresponding author

a.jarzynski87@gmail.com
Contemporarily, influenza virus infection affects $5-25 \%$ of the population worldwide. Associated complications are the cause of many deaths, especially in people from highrisk groups. Pandemics of influenza viruses still present a problem. In 2009, WHO announced a pandemic caused by subtype $\mathrm{A} / \mathrm{H} 1 \mathrm{~N} 1 / \mathrm{v}$, during which 18000 people died [3].

The viral genome is a ssRNA strand of negative polarity, which is divided into seven or eight distinct segments. The virus has a lipid casing which incorporates two main glycoprotein antigens: hemagglutinin (HA), and neuraminidase (NA).

The influenza virus belongs to the Orthomyxoviridae family, which includes three types of viruses:

- Influenzavirus A - occurs in humans and animals, the main reservoir of this virus is waterfowl. This virus is most genetically diverse and variable.

- Influenzavirus B - occurs only in humans. The genome is divided into eight segments. Only one type of virus, having one subtype HA and NA, is distinguished.

- Influenzavirus $\mathrm{C}$ - occurs in humans and pigs. Its structure is different from other types, and is characterized by the absence of neuraminidase. Infection with influenza virus type $\mathrm{C}$ has a milder, often asymptomatic course $[1,4]$. 
Influenza virus infections are often mixed infections and the most common co-infection occur with RSV, coronaviruses (especially OC43/HKU1) and parainfluenza virus type $1[3]$.

Enteroviruses and rhinoviruses. Enteroviruses and rhinoviruses belong to the Picornaviridae family. These are the smallest currently known viruses, their diameter being 20-30 $\mathrm{nm}$. Virions are icosahedral and do not possess a lipid shell. The genetic material of picornaviruses is ssRNA.

The most important of the enteroviruses infecting the respiratory system are the Coxsackie virus and ECHO. Enteroviruses are distinguished from rhinoviruses by acid sensitivity and an ability to grow at a lower temperature.

Coxsackie viruses include two groups: Coxsackie A which has 23 serotypes; Coxsackie B - with six serotypes. Serotypes 9 and 16 (Coxsackie A) are the main cause of pneumonia in infants, while serotypes 4 and 5 (Coxsackie B) may cause pneumonia among adults [9].

ECHO (Enteric Orphan Human Cytopathogenic) is a group of viruses that can cause encephalitis, paralysis symptoms, hepatitis and myositis. There are more than 30 serotypes, and respiratory infection are caused by serotypes $1-7,9,11,16,19,20,22$ and 25 [11].

There are more than 100 serotypes of the rhinovirus. The virus itself has a high antigenic variation. It is possible to distinguish three species of the virus: HRV-A (74 serotypes), HRV-B (25 serotypes) and HRV-C. Rhinoviruses induce rhinitis, throat and sinuses infections, tonsillitis, otitis media, and bronchitis. Patients with asthma, both adults and children, are often prone to rhinovirus infections [7,8].

Objectives of the studyThe aim of the study was to analyze the prevalence of enteroviruses that cause respiratory infections in patients with influenza virus $\mathrm{A} / \mathrm{H} 1 \mathrm{~N} 1$ hospitalized in the Lublin province.

\section{MATERIALS AND METHODS}

Experimental material. The experimental material was throat and nose swabs taken from patients hospitalized in Lublin and Tomaszów Lubelski. After delivering of the material to the laboratory, nucleic acids isolation was prepare by INSTANT Virus RNA Kit (Analytik Jena) and the assay was performed in the direction of the influenza virus by RT-PCR.

Studies towards enterovirus presence were carried out in 44 samples where the influenza virus type A/H1N1 was previously detected. The study group consisted of 24 men $(54.55 \%)$ and 20 women $(45.45 \%)$ patients. The average age of patients was 39 years.

Detection of enteroviruses by RT-PCR. The reverse transcription reaction was carried out using the Revert Aid First Stand cDNA SynthesisKit (Thermo Scientific). The reaction was performed in a Sensoquest thermocycler at $42^{\circ} \mathrm{C}$, for 60 minutes, then quenched at $70^{\circ} \mathrm{C}$, for 5 minutes. The resulting cDNA served for the implementation of the PCR reaction.

For detecting the genetic material of enteroviruses, PCR primers were used, as described by Waris'a et al. [10]. These hybridized to the noncoding 5 'region, and the resulting product had a length of $114 \mathrm{bp}$. The sequences of the primers used in the reaction were:

\section{ENR-R - 5 'GAAACACGGACACCCAAAGTA 3' ENR-F - 5 'CGGCCCCTGAATGCGGCTAA 3'}

The reaction components were: $5 \times$ HOT FIREpol Eva Green qPCR Mix Plus - $4 \mathrm{ml}$; Forward primer (10 pmol $/ \mathrm{ml})$ $-0.3 \mathrm{ml}$; Reverse primer $(10 \mathrm{pmol} / \mathrm{ml})-0.3 \mathrm{ml} ; \mathrm{H}_{2} \mathrm{O}-$ $14.4 \mathrm{ml}$; cDNA - $1 \mathrm{ml}$. The PCR reaction was performed using a touch-down annealing, increasing the specificity of amplification. The reaction profile is detailed in Table 1. Detection of the resulting products was performed using electrophoresis on a $2 \%$ agarose gel.

Table 1. PCR profile

\begin{tabular}{|l|c|c|c|}
\hline \multicolumn{1}{|c|}{ Step } & Temperature & Time & Cycles \\
\hline Initial denaturation & $95^{\circ} \mathrm{C}$ & $15 \mathrm{~min}$ & 1 cycle \\
\hline Denaturation & $95^{\circ} \mathrm{C}$ & $15 \mathrm{~s}$ & - \\
\hline \multirow{2}{*}{ Annealing } & $65-56^{\circ} \mathrm{C}$ & - & $\begin{array}{c}10 \text { cycles } \\
\text { (decrease temp. } \\
\left.\text { of } 1^{\circ} \mathrm{C} / 1 \text { cycle }\right)\end{array}$ \\
\cline { 2 - 4 } & $56^{\circ} \mathrm{C}$ & - & 35 cycles \\
\hline Elongation & $72^{\circ} \mathrm{C}$ & $20 \mathrm{~s}$ & - \\
\hline
\end{tabular}

Identification of rhinovirus. In order to distinguish rhinoviruses from other enteroviruses, we applied the process of digesting the PCR product with a restriction enzyme, and then analyzing the melting curve of the product in RealTime PCR.

Samples were digested with enzyme FokI Fast Digest (Fermentas), according to the manufacturer's instructions. FokI enzyme recognizes the GGATG sequence. To the reaction mixture, $6.7 \mathrm{ml}$ of the PCR product was added and incubated at $37^{\circ} \mathrm{C}$, for 5 minutes, then the digestion was quenched at $65^{\circ} \mathrm{C}$, for 5 minutes. Afterwards, to analyze the size of the restriction digests, electrophoresis on a $2 \%$ agarose gel was carried out. In the case of the Rhinovirus $\mathrm{A}$, the reaction product is digested by FokI. For other enteroviruses lacking a cleavage site, the product does not change size.

The samples where the genetic material of enteroviruses was found, were tested by Real-Time PCR with intercalating dye, and a melting curve analysis was performed. On the basis of differences in the melting temperatures of products, it is possible to differentiate the viruses. In the case of rhinoviruses, the melting point is lower than with the other enteroviruses [8].

\section{RESULTS}

In the group of 44 patients (20 women and 24 men) infected with influenza $\mathrm{A} / \mathrm{H} 1 \mathrm{~N} 1$, the genetic material of enteroviruses was detected in 13 patients $(29.5 \%)$. Enteroviral infection was detected in 6 women ( $30 \%$ of the samples) and in 7 men (29.2\% of the samples). The results in men and women were similar, suggesting no relation to gender in the occurrence of enterovirus infections. Most of the patients were adults $(32 ; 72.2 \%)$. Positive results obtained in this group were obtained for $21.9 \%$ of the samples. 12 samples were taken from children up to 9 years of age $(27.3 \%)$. 
Enterovirus infections were found in $50 \%$ of them. Infections were more often detected in children than in adults. In the study, patients were placed into age groups. Three groups of patients (11-20 years, 31-40 years, 41-50 years) were not diagnosed with the influenza virus and enteroviruses co-infection. However, in children, the number of positive samples was significantly higher than in adult patients.

Table 2. Results of studies

\begin{tabular}{|l|c|c|}
\hline & Positive $(n=13)$ & Negative $(n=31)$ \\
\hline Women $(n=20)$ & $6(30 \%)$ & $14(70 \%)$ \\
\hline Men $(n=24)$ & $7(29,2 \%)$ & $17(70,8 \%)$ \\
\hline Children $(n=12)$ & $6(50 \%)$ & $6(50 \%)$ \\
\hline Adults $(n=32)$ & $7(21,9 \%)$ & $25(78,1 \%)$ \\
\hline
\end{tabular}

Melting curve analysis. Melting curve analysis clearly indicated rhinovirus infection in only one clinical sample. The reaction product was subjected to sequencing to confirm the result. The result of sequencing showed this to be rhinovirus A. For the remaining trials, the results were inconclusive, which, we think, means that the test method needs to be optimized

Restriction digest. After electrophoresis, in three samples, changes in product length were observed. This may indicate the existence of the FokI cleavage site. The sample of rhinovirus were taken from people aged 1, 27 and 78 years. Rhinovirus infection type A occurred in $23 \%$ of all diagnosed enterovirus infections.

\section{DISCUSSION}

A large number of infections involve co-infections with other respiratory viruses. Studies conducted by Martin et al., show that co-infection occurs in $18 \%$ of all respiratory viruses infections. The most common combinations include the influenza virus with: RSV A, RSV B, coronavirus OC43/ HKU1 and parainfluenza virus type 3. Martin et al. reveal that among double infections, the most common combinations are: $\mathrm{AdV} / \mathrm{RSV}, \mathrm{RSV} / \mathrm{CoV}$ and $\mathrm{AdV} /$ Influenza. Of note, virological diagnosis is rarely carried out in various directions, usually ending on the detection of one pathogen alone, which prevents detection of co-infections [6].

Many publications confirm the existence of respiratory virus co-infections. Johnston et al. examined 292 samples from children aged 9-11 years, and viruses were detected in 226 samples. Moreover, in 147 samples, picornaviruses were present. In 21 samples, the influenza virus was detected. Furthermore, 14 patients were infected with two viruses, and in one patient three viruses were found at the one time [5].
Our study also indicates a high incidence of respiratory virus co-infections. In patients infected with influenza A/ $\mathrm{H} 1 \mathrm{~N} 1$, tests were carried out only in the direction of enteroviruses, yet co-infections were detected in $29.5 \%$. Of note, there is a high probability of detecting a virus when testing for other respiratory pathogens. Yet, it cannot be stated that the state of the patients with co-infections deteriorated, because there is no clinical data.

Respiratory viruses co-infections are very common in hospitalized patients. Studies, such as ours, show that coinfection with influenza virus and enterovirus are more common in children than in adults. What is more, viral respiratory tract infections are independent from the patients' gender.

\section{REFERENCES}

1. Brydak L.B.: Influenza - a problem as old as the world. Hygiea Public Health, 47 (1), 1-7, 2012.

2. Brydak L.B.: News diagnostics, therapy and prevention of viral respiratory tract infections. Przewodnik lekarza, 147-153, 2007.

3. Brydak L.B.: Infection caused by respiratory viruses and the possibility of controlling them. Polski Merkuriusz Lekarski, 355-358, 2011.

4. Brydak L.B., Zycinska K.: Influenza and it's prevention - still current medical problem. Polskie Archiwum Medycyny Wewnentrznej, 117 (10), 464-469, 2007.

5. Johnston S.L. et al.: Community study of role of viral infections in exacerbation of asthma in 9-11 year old children. BMJ, 310, 12251229, 1995.

6. Martin T.E. et al.: Multiple versus single respiratory infections: viral load and clinical disease severity in hospitalized children. Influenza Other Respiratory Viruses, 6 (1), 71-77, 2012.

7. Messacar K. et al.: Rhino/Enteroviruses in hospitalized children: a comparison to influenza viruses. J Clinl Vir, 56 (1), 41-45, 2013.

8. Peltola V. et al.: Rhinovirus transmission within families with children: incidence of symptomatic and asymptomatic infections. $J$ Infect Dis, 197, 382-389, 2008.

9. Rajtar B. et al.: Enteroviruses in water environment - a potential threat to public health. Ann Environ Med. 15, 199-203, 2008.

10. Waris M.: Comparison of sampling methods for detection of human rhinovirus RNA. J Clin Vir. 58, 200-204, 2013.

11. Witek A., Wieczorek M.: Virologic and molecular studies in enteroviruses infections in Poland in 2004-2008. Przeg Epid, 63, 381-384, 2009. 